\author{
Katarzyna RAGIN-SKORECKA ${ }^{1}$ \\ Magdalena WYRWICKA ${ }^{2}$
}

\title{
IDENTIFYING THE POTENTIAL OF GREATER POLAND TO DEVELOP COOPERATION NETWORKS
}

Foresight, a tool for creating common future (visions), relies on monitoring significant developments and formulating strategic objectives for enterprises, sectors or regions. The article presents a comparative analysis of the findings of identity studies carried out in 2010 and 2016 in the Region of Greater Poland (also referred to by its Polish name of Wielkopolska) as part of a foresight project that relied on business networks to foster innovation. Region's identity translates into its potential and propensity to change, as it is interpreted as the synergy of key skills and common values, The discussion below identifies trends in building the region's identity and shows whether such an identity will support the development of cooperation networks.

The above research has shown an identity as being a factor in the assessment of coexisting formal structures and relationship networks, which constitutes a significant potential of a region. While noting the incorporation of regional identity into foresight research, the authors emphasize the need for regular studies. Knowledge on regional identity helps formulate measures that support a sense of community and reveal the opportunities which the decision-makers involved in building Innovative Wielkopolska can use to make a difference. The study findings show that significance of identity components changes along with transformations in public expectations.

Keywords: foresight, region's identity, shaping of networks, potential, Wielkopolska (region in Poland)

\section{INTRODUCTION}

A study carried out at the Poznan University of Technology between 2009 and 2011 within the framework of the project "Foresight - Wielkopolska Business Networks knowledge transformation scenarios in support of innovative economy" has suggested that Wielkopolska's developmental transition should begin with defining the Region's strategic identity (i.e., specifically, the shared values and key competencies that define it), systemic measures aimed at promoting entrepreneurship and network initiatives, preparing and coordinating programs to foster research and development cooperation, helping disseminate knowledge via business support institutions and among businesses and stimulating the development of social capital ${ }^{3}$. By identifying such potential, that is

\footnotetext{
${ }^{1}$ Katarzyna Ragin-Skorecka, PhD, Eng, Poznan University of Technology, Faculty of Engineering Management, Poland

${ }^{2}$ Magdalena Wyrwicka, DSc, PhD, Eng., Poznan University of Technology, Faculty of Engineering Management, Poland

${ }^{3}$ M.K. Wyrwicka, Wstęp [in:] M.K.Wyrwicka, Foresight „Sieci gospodarcze Wielopolski” scenariusze transformacji wiedzy wspierajace innowacyjna gospodarkę. Raport końcowy., Wydawnictwo Politechniki Poznańskiej, Poznań, 2011, pp. 5-12
} 
locally available capacities and tangible as well as intangible resources, a launching pad will be formed for realistic development scenarios.

Defined as learning organizations, whose knowledge is transferred among individual actors, regions aspire, as their key purpose, to seek to disseminate their knowledge and have it used for experimentation (in the pursuit of innovation). Knowledge is a resource that grows along with increases in the number of its applications. This is because practical applications of knowledge help better understand the underlying causes and principles. As knowledge is disseminated (diffused) via networks, new skills and competencies are acquired and critical issues are identified. As a consequence, knowledge is built and disseminated across a shared value network through human interactions which allow information to be transferred across organization structures ${ }^{4}$. One's identification with a specific location or institution and one's dedication to pursue structural improvements and modifications can well be identified by reference to identity. The article relies on a method developed by K. Ragin-Skorecka ${ }^{5}$ and applied to assess the identity of the Wielkopolska Region in 2010 and 2016 studies.

The resulting comparative material outlines the transitions witnessed in the Wielkopolska Region helping one to reassess the existing potential for implementing the concept of Innovative Wielkopolska which the Region has pursued for a number of years.

\section{METHODOLOGY FOR INVESTIGATING THE POTENTIAL OF THE WIELKOPOLSKA REGION}

\subsection{The use of foresight to prepare for the future}

The term "foresight" was coined by J.F. Coates, who defined it as "a process by which one comes to a fuller understanding of the forces shaping the long-term future which should be taken into account in policy formulation, planning and decision-making"6. K. Safin sees foresight as a process that enables one to "preempt various possible variants of the future and prepare responses to the most likely events"7. Foresight is a process that encompasses recurring periods of reflection followed by the construction of networks which incorporate diverse social groups. It relies on social consultation and debates among various stakeholders. In its multiple scenarios, foresight research follows the stages of:

1) analysis (quantitative as well as qualitative),

2) model development (relationship networks, process modeling),

3) verification by way of social consultations,

4) development of deployment precepts (scenarios).

The procedure leads to building a shared multi-faceted outlook while ensuring widespread identification with the adopted strategy. Foresight is employed to explore

\footnotetext{
${ }^{4}$ K. Perechuda, Dyfuzja wiedzy w przedsiębiorstwie sieciowym. Wizualizacja $i$ kompozycja. Wydawnictwo Uniwersytetu Ekonomicznego we Wrocławiu, $3^{\text {rd }}$ edition, expanded, Wrocław, 2013.

${ }^{5}$ K. Ragin-Skorecka, Management of Internal Corporate Identity, Wydawnictwo Politechniki Poznańskiej, Poznań, 2010.

${ }^{6}$ J.F. Coates, Foresight in Federal Government Policy Making, Futures Re-search Quarterly, No 1., 1985, p. 30.

${ }^{7}$ K. Safin, Geneza, istota i typy foresight, [in:] K. Safin, Foresight jako metoda kształtowania przyszłości. Identyfikacja potencjału i zasobów Dolnego Ślaska w obszarze nauka i technologie na rzecz poprawy jakości życia, Wydawnictwo Uniwersytetu Ekonomicznego we Wrocławiu, Wrocław, 2011, pp. 15-16.
} 
long-term potentials resulting from the impact of science and innovation on the general public. The perceptions of the future, commonly represented in foresight surveys as individual scenarios, rely on diagnoses of the status quo, assessments of the development potential, the identification of trends and attempts to identify mechanisms triggered by the decisions of various interest groups. An actively created vision of the future combines the items monitored, trends and impacts on the future seen vis-à-vis the development trends desired by decision-makers. Therefore, foresight research begins with attempts to identify and analyze the status quo in the recognition that the future results from past and present actions.

With respect to the Region of Greater Poland, the foresight research has focused on networking, the diffusion of innovative ideas and institutions which support businesses and regional identity, all of which helped assess the current potential.

\subsection{Procedure for assessing growth opportunities}

Regional development relies on the accumulated resources to create growth poles and differentiate structures by polarizing the economy. Such growth poles emerge, evolve and fade away through the spread of innovation and the impact of development incentives. Discrepancies in regional development arise over time through the operation of causeand-effect mechanisms within the existing structures. Such feedback mechanisms generate positive or negative reinforcement (respectively triggering either growth or recessions). By recognizing significant resources and relationships as well as measures and incentives that stimulate or impede growth or recessions, decision-makers and local authorities formulate their regional policies and intervene in the process. Therefore, relevant research and assessments are focused on networks. In a network, borderlines between individual network components become blurred. This is because less attention is being paid to formal limitations while priority is given to relationships across and within the individual components. A network's cohesion is achieved by ensuring that its components are sufficiently diverse so as to secure and guide the initiatives of individual entities. A key to assessing the development potential of a given region is to identify the characteristics of its network. Note that the view that networks are multifaceted, commonplace and beyond one's grasp preempt debates on whether network mechanisms operate properly. Networks, which have become ubiquitous, are often seen as backgrounds to formal organizations. Researchers commonly forego attempts to identify the differences between structures and networks. As a consequence, they resort to the term "network organization" which implies unpredictability. This approach is justified with the growing complexity, environmental pressures, orientation issues, uncertainty and data overload.

If organizations and networks are recognized as suited to face different challenges, one will naturally expect that different research methods and approaches to their description be used for their assessment. Nevertheless, operating realities and pragmatics make it necessary to assess circumstances in which networks and structures coexist. For that reason, the authors assume that a key to synthetically assessing the status quo is to define the identity of an organization. 
Fig. 1. Characteristics of regional identity

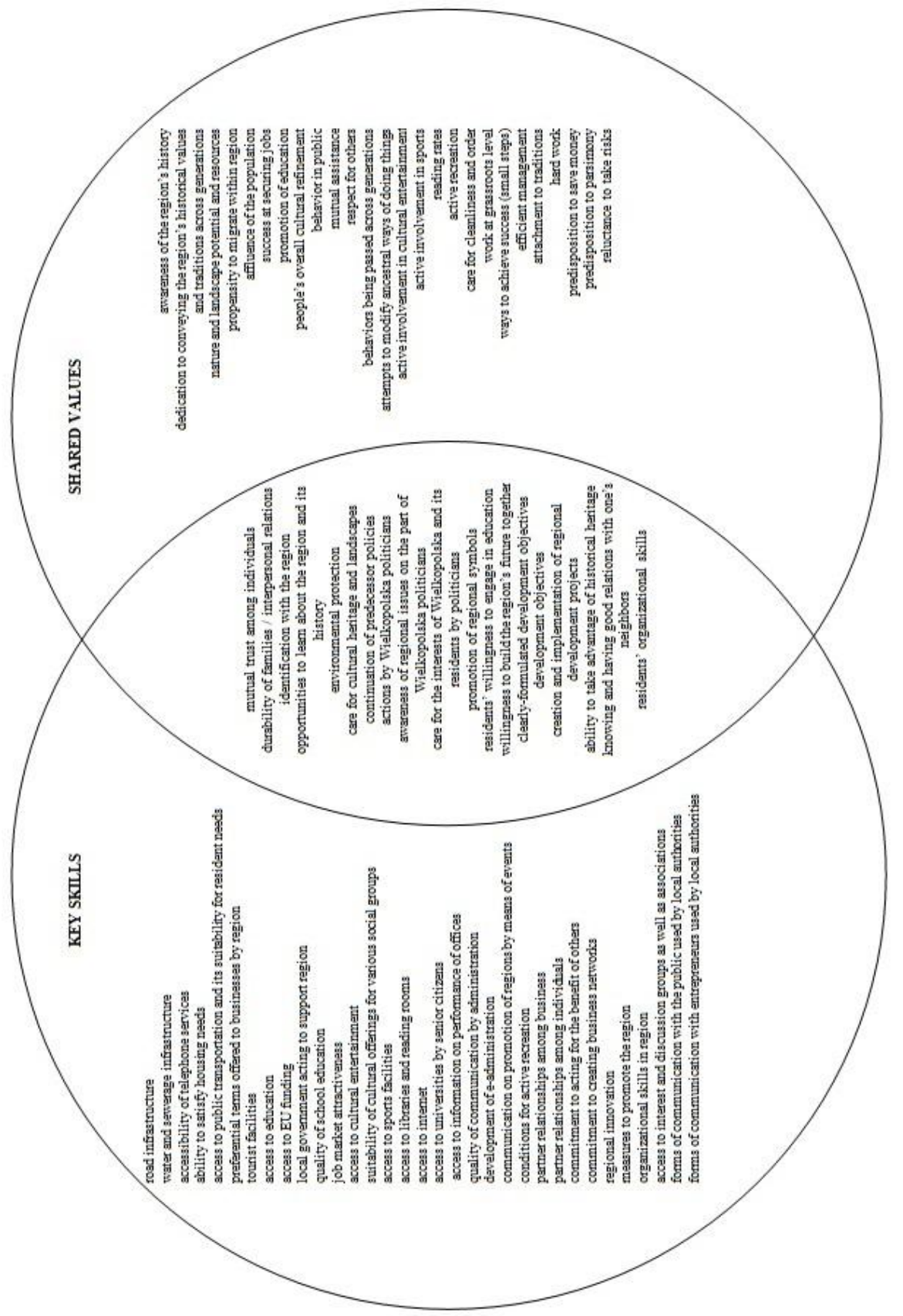

Source: (Ragin-Skorecka, 2010a, p. 20) 


\subsection{Regional identity}

Scholars vary in the definitions of organizational identity they adopt depending on their research perspectives ${ }^{8}$. Zarębska ${ }^{9}$ defines organizational identity as an ethos that expresses the aims and values of significance for an organization and that presents the rationale for individuality that helps distinguish oneself in a competitive market". Identity helps present organizations to target groups - they are a planned self-presentation which relies on a specified strategy. Pacholski and Wyrwicka ${ }^{10}$ compare organizational identity to "a genetic code which determines the predispositions and traits manifested by a given organism, which may either be improved during its lifetime or left unexpressed and unutilized". To ensure terminological consistency, organizational identity has been defined as "a system of mutually complementary features of an organization which distinguish it individually, ensure its stability and consistency and contribute to its internal and external reputation". Identity has been assumed to manifest itself through an organization's reputation, reputation being a notion broader than image and affording deeper insights into the complexities of identity ${ }^{11}$.

Regions (voivodships) are the highest-level units of administrative subdivision in Poland as well as the highest echelon of local governments ${ }^{12}$. Being highly autonomous entities, regions resemble organizations. Having recognized this, one may proceed to a discussion on regional identity and a region's stakeholders.

The identity of a Voivodship is a system of the region's complementary features which distinguish it from others and which contribute to its stability, cohesion as well as internal and external reputation. The features that make up a region's identity are defined with emphasis on the good intentions that underpin them and how they are evaluated.

The variables that make up a region's identity can be divided into the three categories (Fig. 1) of shared values, key skills and the overlap between the two. Key skills provide the region with an advantage helping it stand out from among other regions. These features are susceptible to change - they can be fashioned to ensure the achievement of the specific objectives of a region and its residents. Shared values are a blend of cultural transformations, stereotypes and local traditions. They are acquired and evade control as many of them do not become absorbed into the collective awareness of the region's local community. The overlap between the two is an area of a region's own values which are

\footnotetext{
${ }^{8}$ S. Albert, D.A. Whetten, Organizational identity: Organizational identity, New York. Oxford University Press, 2004; J.M.T. Balmer, Corporate identity: the power and paradox, Design Management Journal, Winter, 1995; J. Dutton, J. Dukerich, Keeping an eye on the mirror: the role of image and identity in organizational adaptation, Academy of Management Journal, vol. 34, 1991; Hong-Wei He, J.M.T. Balmer, Identity studies: multiple perspectives and implications for corporate-level marketing, European Journal of Marketing, vol. 41, no. 7/8, 1997; Strategor, Zarzadzanie firma, Polskie Wydawnictwo Ekonomiczne, Warszawa, 1996; C.B.M. van Riel, J.M.T. Balmer, Corporate identity: the concept, its measurement and management, European Journal of Management, vol. 31 no. $5,1997$.

${ }^{9}$ A. Zarębska, Identyfikacja tożsamości organizacyjnej w zarządzaniu przedsiębiorstwem, Warszawa, Wydawnictwo Difin, 2009

${ }^{10}$ L.M. Pacholski, M.K. Wyrwicka, Tożsamość przedsiębiorstwa, Zeszyty Naukowe Politechniki Poznańskiej, no. 49, Poznań, 2007.

${ }^{11}$ K. Ragin-Skorecka, Corporate identity, Wydawnictwo Politechniki Poznańskiej, Seria Monografie Poznan, 2010.

${ }^{12}$ A. Adamus-Matuszyńska, Wizerunek jak opoka, Marketing w Praktyce, no. 10, 2003.
} 
also key skills and which, under proper conditions (or circumstances) become controllable ${ }^{13}$

\section{SELECTED RESEARCH OUTCOMES}

\subsection{Study outline}

The study's objective was to assess the identity of the region and identify its key properties that translate into the regional identity. The findings additionally helped identify the region's features and the ways changes were attempted to improve the region's perception.

The study relied on a survey questionnaire comprised of 78 questions referring to the tree of the region's identity features. Responses to these closed-ended questions could be selected on a seven-point scale ranging from the lowest score (weight) of 1 to the highest score of 7 . The identity scores were used to evaluate two aspects. One was the respondent's assessment of the present state of a given regional identity component. The other indicated the significance of the component in developing the region's identity. The respondents' input helped define the region's identity broken down by respondent groups as well as identify the key elements of the region's identity and rank them by importance.

The first such surveys were conducted in 2010 as part of the research project "Foresight - Wielkopolska Business Networks - knowledge transformation scenarios in support of an innovative economy". Carried out in Wielkopolska, the survey involved a representative sample of five respondent groups. The responses were contributed by 800 residents, 200 local government officials, 50 representatives of the news media, 50 business managers, and 100 research scholars. The sample and its weighing was designed to ensure representativeness across the individual subregions of Wielkopolska (the subregions of Poznań, Kalisz, Leszno, Piła and Konin).

The survey was repeated in 2016, this time covering 50 respondents as it was not possible to include a larger population. Due to the small size of the sample, the interpretation of the outcomes will not be broken down by subregions but rather generalized over the entire region of Wielkopolska.

The region's identity was assessed and the key identity components that require change to improve its perception identified by means of an own tool relying on fuzzy logic and factor analysis ${ }^{14}$.

\subsection{The identity of Wielkopolska}

The majority of the region's identity components are soft factors which escape assessment by hard criteria. As the evaluations were expressed in a natural language, it was necessary to employ the tool of Fuzzy Identity Indicator. The interpretation focused on a triangular fuzzy number which is diffused and consequently translated into an understand-

\footnotetext{
${ }^{13}$ K. Ragin-Skorecka, Diagnoza tożsamości Wielkopolski, [in:] M.K. Wyrwicka, Tendencje rozwojowe Wielkopolski w kontekście transformacji wiedzy w sieciach gospodarczych, Wydawnictwo Politechniki Poznańskiej, Poznań, 2010, pp. 15-58.

${ }^{14}$ K. Ragin-Skorecka, Management of Internal Corporate Identity, Wydawnictwo Politechniki Poznańskiej, Poznań, 2010.
} 
able description of a region's identity. The tool and its underlying algorithm are presented in $^{15}$.

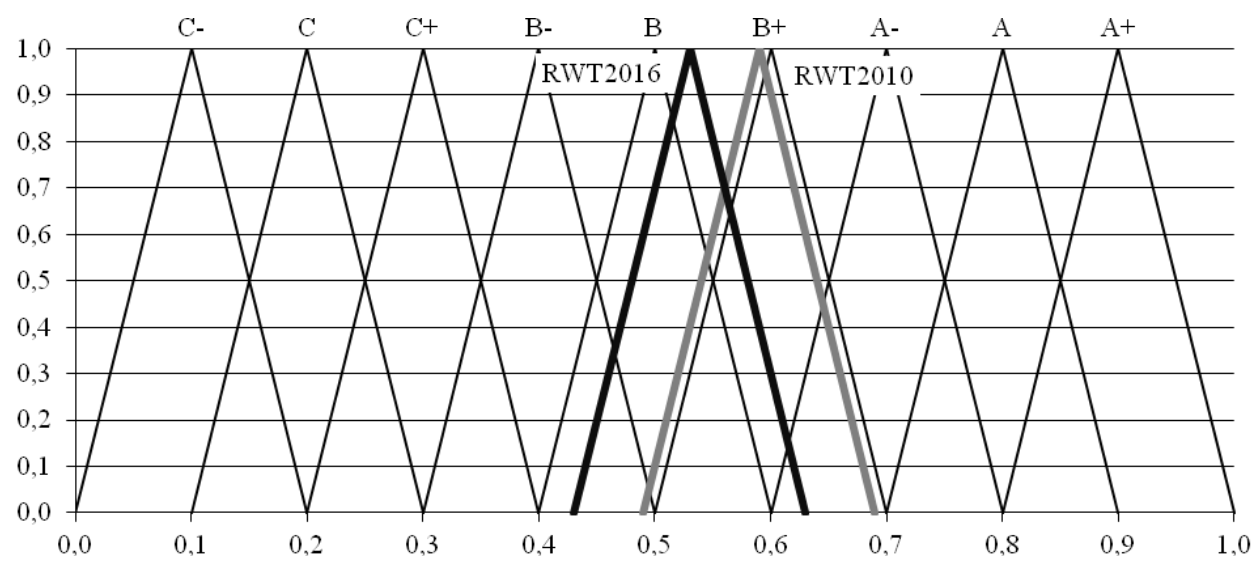

Fig. 2. Fuzzy Identity Indicators for Wielkopolska in 2010 and 2016

Source: Own research

An analysis of the outcomes received from the entire study population showed that the identity of Wielkopolska deteriorated in 2016 approximating model level B. This means that the region's identity is made up of a neutral reputation and a neutral image. In 2010, the region's identity was close to level B+ (Fig. 2). The outcome and its comparison with the previous findings suggest the upsetting conclusion that Wielkopolska's identity is in decline.

\subsection{Key identity variables}

The Fuzzy Identity Indicator can be used to identify areas that are key to developing a strong regional identity. Changes in these variables should be recognized as a top priority. Fig. 3 shows the regional identity components whose Fuzzy Identity Indicators were the highest in 2016 and 2010. Respondents in 2016 pointed to 7 and those in 2010 to 8 variables that are key to the entire population whose Fuzzy Identity Indicators ranked high.

A comparison of the 2016 and 2010 results shows improvements in the regional identity components for the components of continuation of predecessor policies, propensity to migrate within the region, attempts to modify ancestral ways of doing things, predisposition to parsimony and reluctance to take risk. Such findings are interesting as the characteristics fall into the area of own values which can hardly be controlled at the level of the organization, i.e. e.g. the level of regional authorities or entities operating in the region.

No improvements were seen in the areas of access to universities by senior citizens, access to interest and discussion groups and partner relationships among businesses. All of the above are controllable variables set out in the category of key competencies. Particular attention at the regional level should be paid to the variable of partner relationships among businesses as a critical success factor in Wielkopolska.

\footnotetext{
${ }^{15}$ K. Ragin-Skorecka, Diagnoza tożsamości Wielkopolski, [in:] M.K. Wyrwicka, Tendencje rozwojowe Wielkopolski w kontekście transformacji wiedzy w sieciach gospodarczych, Wydawnictwo Politechniki Poznańskiej, Poznań, 2010, pp. 15-58.
} 


\section{6}

L4 - ability to satisfy housing needs (KS)

L8 - access to education (KS)

L13 - access to cultural entertainment (KS)

L14 - suitability of cultural offerings for various social groups (KS)

L16 - access to libraries and reading rooms (KS)

L24 - communication on promotion of regions by means of events (KS)

L26 - availability of active leisure pursuits (KS)

L28 - partner relationships among individuals (KS)

L29 - mutual trust among individuals $(\mathrm{KS}+\mathrm{SV})$

L32 - commitment to creating business networks (KS)

L33 - development objectives (KS+SV)

L34 - level of regional innovation (KS)

L37 - opportunities to learn about the region and its history $(\mathrm{KS}+\mathrm{SV})$

L39 - care for cultural heritage and landscapes (KS+SV)

$\mathrm{L40}$ - continuation of predecessor policies $(\mathrm{KS}+\mathrm{SV})$

L41 - actions taken by Wielkopolska politicians (KS+SV)

L51 - ability to take advantage of historical heritage (KS+SV)

L59 - behavior in public (SV)

L60 - mutual assistance (SV)

L61 - respect for others (SV)

\section{0}

L25 - forms of communication with businesses used by local governments (KS)

L33 - development objectives $(\mathrm{KS}+\mathrm{SV})$

$\mathrm{L40}$ - continuation of predecessor policies $(\mathrm{KS}+\mathrm{SV})$

L41 - actions taken by Wielkopolska politicians $(\mathrm{KS}+\mathrm{SV})$

L42 - awareness of regional issues among Wielkopolska politicians (KS+SV)

L43 - politicians' care for the interests of Wielkopolska and its residents (KS+SV)

L46 - clearly-formulated development objectives (KS)

L47 - development and implementation of regional development projects $(\mathrm{KS}+\mathrm{SV})$

L68 - care for cleanliness and order (SV)

L70 - ways to achieve success (small steps) (SV)

L71 - cost efficiency (SV)

L72 - the region's organizational skills (KS)

L73 - attachment to traditions (SV)

L74 - dedication to hard working (SV)

Fig. 4. Regional identity components of high significance as identified in 2010 and 2016

Source: Own research

A comparative analysis of the Fuzzy Significance Indicator and factor analysis outcomes points to the key regional identity variables that require modification. In 2016, these were:

- $\quad$ access to libraries and reading rooms,

- commitment to creating business networks,

- development objectives. 
The above characteristics fall into the key skills (KS) category, which makes them controllable variables. Of particular importance for Wielkopolska's economic development is the focus on selecting adequate development objectives and ensuring the support and engagement of public administrative authorities in the creation of economic networks.

\section{CONCLUSIONS}

The above research has shown identity as being a factor in the assessment of coexisting formal structures and relationship networks, which constitutes a significant potential of a region. While noting the incorporation of regional identity into foresight research, the authors emphasize the need for regular studies. Knowledge on regional identity helps formulate measures that support a sense of community and reveal the opportunities which the decision-makers involved in building Innovative Wielkopolska can use to make a difference. The study findings show that significance of identity components changes along with transformations in public expectations. However, one should note that a number of significant factors remain unaffected by economic and political developments. Such identity components should be taken under "particular care" and be used as a tool for integrating the local community.

Furthermore, by identifying variables that can be controlled by regional authorities, the study points to opportunities to take action and make a difference thus facilitating measures that promote growth and help achieve the desired aims.

\section{REFERENCES}

[1] Adamus-Matuszyńska A. (2003). Wizerunek jak opoka. Marketing w Praktyce, no. 10.

[2] Albert S., Whetten D.A. (2004). Organizational identity: Organizational identity. New York. Oxford University Press.

[3] Balmer J.M.T. (1995). Corporate identity: the power and paradox. Design Management Journal. Winter.

[4] Coates J.F. (1985). Foresight in Federal Government Policy Making, Futures Re-search Quarterly, No 1 .

[5] Dutton J., Dukerich J. (1991). Keeping an eye on the mirror: the role of image and identity in organizational adaptation. Academy of management Journal, vol. 34.

[6] Hong-Wei He, Balmer J.M.T. (2007). Identity studies: multiple perspectives and implications for corporate-level marketing. European Journal of Marketing, vol. 41, no. 7/8.

[7] Pacholski L.M., Wyrwicka M.K. (2007). Tożsamość przedsiębiorstwa. Poznań. Zeszyty Naukowe Politechniki Poznańskiej, no. 49.

[8] Perechuda K. (2013). Dyfuzja wiedzy w przedsiębiorstwie sieciowym. Wizualizacja i kompozycja. Wydawnictwo Uniwersytetu Ekonomicznego we Wrocławiu, $3^{\text {rd }}$ edition, expanded. Wrocław.

[9] Ragin-Skorecka K. (2010a). Diagnoza tożsamości Wielkopolski. [in:] Tendencje rozwojowe Wielkopolski w kontekście transformacji wiedzy w sieciach gospodarczych. red. Wyrwicka M. K., Wydawnictwo Politechniki Poznańskiej. Poznań. pp. 15-58.

[10] Ragin-Skorecka K. (2010b). Management of Internal Corporate Identity. Wydawnictwo Politechniki Poznańskiej. Poznań.

[11] Ragin-Skorecka K. (2010c). Corporate identity. Wydawnictwo Politechniki Poznańskiej. Seria Monografie. Poznań.

[12] Safin K. (2011) Geneza, istota i typy foresight, [in:] Foresight jako metoda kształtowania przyszłości. Identyfikacja potencjału i zasobów Dolnego Śląska w obszarze nauka i technologie na rzecz poprawy jakości życia. ed. Safin K., Wydawnictwo Uniwersytetu Ekonomicznego we Wrocławiu, Wrocław. 
[13] Strategor (1996). Zarządzanie firmą. Polskie Wydawnictwo Ekonomiczne. Warszawa.

[14] van Riel C.B.M., Balmer J.M.T. (1997). Corporate identity: the concept, its measurement and management. European Journal of Management, vol. 31 no. 5.

[15] Wyrwicka M. K. (2011). Wstęp [in:] Foresight 'sieci gospodarcze Wielopolski' scenariusze transformacji wiedzy wspierające innowacyjną gospodarkę. Raport końcowy. red. Wyrwicka M. K., Wydawnictwo Politechniki Poznańskiej. Poznań. pp. 5-12.

[16] Zarębska A. (2009). Identyfikacja tożsamości organizacyjnej w zarządzaniu przedsiębiorstwem. Warszawa. Wydawnictwo Difin.

\section{IDENTYFIKACJA POTENCJAŁU WIELKOPOLSKI W KSZTAETOWANIU SIECI WSPÓLPRACY}

Foresight, jako narzędzie kreowania wspólnej przyszłości (wizji), zakłada monitorowanie istotnych zjawisk i wytyczanie kierunków strategicznych dla przedsiębiorstw, branż lub regionów. Artykuł pokazuje analizę porównawczą wyników badań tożsamości Wielkopolski (przeprowadzone w roku 2010 i 2016), realizowaną w ramach foresightu dotyczącego proinnowacyjnego oddziaływania sieci gospodarczych. Tożsamość regionu, jako synergia umiejętności kluczowych i wartości wspólnych stanowi o potencjale regionu i gotowości do przeobrażeń. Prezentowana tu analiza pozwala dostrzec w jakim kierunku przeobraża się tożsamość regionu i czy będzie wspierać kształtowanie sieci współpracy.

Wyniki prezentowanych badań pokazują tożsamość jako parametr oceny współistnienia struktur formalnych i sieci powiązań, która stanowi istotny potencjał regionu. Zwracając uwagę na ulokowanie tożsamości regionu $\mathrm{w}$ badaniach foresight, autorki podkreślają potrzebę prowadzenia cyklicznych badań. Wiedza o tożsamości regionu wytycza kierunki działań wspierających poczucie wspólnoty i ujawnia możliwości sprawcze decydentów budujących Innowacyjną Wielkopolskę. Uzyskane rezultaty badań pokazują, że istotne elementy tożsamości zmieniają się, gdyż przemianom ulegają oczekiwania społeczności. Warto jednak dostrzec, że ważność niektórych czynników pozostaje niezmienna, nie podlega dynamice sytuacji gospodarczej i politycznej. Te składowe tożsamości powinny być „pod szczególną opieką" i być obiektem działań integrujących lokalna społeczność.

Prezentowane badanie pokazuje również możliwości sprawcze, identyfikując zmienne sterowalne z punktu widzenia władz regionu, co powinno ułatwiać wprowadzanie zmian prorozwojowych i ukierunkowanie funkcjonowania na pożądane cele.

Słowa kluczowe: foresight, tożsamość regionu, współpraca w sieci, potencjał, Wielkopolska

\section{DOI: 10.7862/rz.2016.mmr.52}

Tekst złożono w redakcji: październik 2016

Przyjęto do druku: grudzień 2016 
